\title{
Modern Standard Arabic and Rural Palestinian Dialect: Patterns of the Active Participle
}

\author{
Mohammed Mahmoud Talal Mohaidat ${ }^{1}$ \\ ${ }^{1}$ Department of English Language and Literature, College of Arts, King Saud University, Riyadh, Kingdom of \\ Saudi Arabia \\ Correspondence: Mohammed Mahmoud Talal Mohaidat, Department of English Language and Literature, \\ College of Arts, King Saud University, Riyadh, Kingdom of Saudi Arabia. E-mail: mmohaidat@ksu.edu.sa
}

Received: October 24, 2016

Accepted: December 1, 2016 Online Published: May 29, 2017

doi:10.5539/ies.v10n6p130

URL: https://doi.org/10.5539/ies.v10n6p130

\begin{abstract}
This paper was mainly concerned with analyzing the processes of active participle formation in Modern Standard Arabic (MSA). It also aimed to examine the Rural Palestinian Dialect (RPD) in order to reveal the derivation of the active participle in this dialect and to describe any patterns that might vary from MSA. The study was based on the traditional notions of root and pattern which characterize Arabic morphology. The data for this study were collected from various sources. These sources are not researchers but they are people originated from Palestine. Then the data were analyzed in terms of morphology.
\end{abstract}

Keywords: word-formation, active participle, root, pattern

\section{Introduction}

Arabic is a Semitic language spoken by around 350 million people, but it is understood among Muslims around the world that is four times larger, (Abdel-Monem et al., 2009). In Arabic, there is classical Arabic, Modern Standard Arabic (MSA) and spoken Arabic. Classical Arabic is the Arabic used in the Qur'an and in the Arabian literature. MSA is the variety of Arabic which is used as the official language in Arab countries. Ziadeh and Winder (2003) report that MSA is widely used in the "media, official documents, correspondence, education and as a liturgical language," (p. 122).They add that it is a modern variant of classical Arabic and it is learned at school and in the daily news, religious practice, and print media. Spoken Arabic, on the other hand, which is often referred to as colloquial Arabic or dialects is a mixed form, which has many variations. These variations may be difficult to understand from one area to the other (Ziadeh \& Winder, 2003). Thus, an important quality of the Arab communities is the existence of diglossia. According to Ferguson (1959), diglossia is a characteristic feature of the Arabic world and MSA is the language used for writing but it is not a native language of anyone.

The Arabic language is morphologically based on the notion of the root, which are three consonants which show a meaning. According to Aronoff (1994), the nature of Semitic languages' morphology is clear when one considers that "roots are mere collections of consonants from which all individual word-forms are quite dramatically given form by the laying of templates and affixes," (Aronoff 1994, p. 3). Ryding (2005) also defines the root as a "relatively invariable discontinuous bound morpheme" which has a lexical meaning (p. 47). Neme and Laporte (2013) agree with the Aronoff and Ryding and add that the grammatical differences among these forms make new patterns as the lexical items are classified as biliteral, triliteral, quadriliteral, quinqueliteral depending on how many letters the root has (Neme \& Laporte, 2013).

According to Hudson (1985), the application of MSA morphological pattern rules is not difficult. He explains the traditional Semitic grammarians have documented a few examples to show derivational processes, but these examples are effective and the patterns are very clear, and they prove that root and pattern morphologies are not difficult to learn.

The morphological patterns of MSA are used in the colloquial varieties; however, new patterns have arisen by time. These patterns need to be studied as the dialect is considered a powerful means of communication which has its own characteristic features which make it unique. Many studies were conducted in order to investigate the linguistic variability in the Palestinian Arabic. However, few of these studies concentrated on the morphological patterns of the active participle. So, the researcher believed that this study might generate interest in this issue. 
This study aimed to analyze the formation of the active participle in MSA. It intended to explore the patterns used in MSA and the Rural Palestinian Dialect (RPD). The researcher believed that an understanding of the manner in which the active participle is derived might have important implications on understanding the morphological variation between this dialect and MSA.

The linguistic description which this study presents was of two parts, the morphological features of the Active Participle in MSA and PRD. The data for the first part came from the studies which examined the active participle in MSA. The data concerning the Palestinian dialect were gathered by the researcher from individuals of a Palestinian background, including the researcher's family as a native Palestinians. The researcher, then, analyzed the data collected in order to reveal the PRD patterns which may be inconsistent with MSA.

\section{MSA Morphology}

Bohas and Kouloughli (2006) mentioned that the traditional schools which had a great role in establishing Arabic grammar are the Kufa School and the Basra School. These two schools agree that the majority of the Arabic lexis have a trilateral root ( $\mathrm{f}$ C $\mathrm{l}$ ). Alkaleel-Bin-Ahmed used this root as a criterion for rhyming in poetry.

To convey information, the Arabic language uses sounds (Ryding, 2014). With these sounds, it creates patterns or templates where roots fit and by which stems are produced and inflected. These sounds are called zawaa Rid in Arabic (singular zaa Tida)) and are usually referred to as formatives in English terms as they are used to form words. Aronoff (1994) defines formatives as "serving to form words: said chiefly of flexional and derivative suffixes," (Aronoff, 1994, p. 2). Ryding (2014) mentions that Semitic vowels are components of derived word-stems and form three long and three short: /aa/, /ii/, /uu/, /a/, /i/, and /u/, whereas the consonantal derivational affixes used in Arabic are: hamza, taa?, miim, nuun, siin, yaa?, and waaw. These thirteen forms (six vowels and seven consonants) form the patterns in Arabic (Ryding, 2014, p. 65).

Morphologists used these patterns as a morphological scale to indicate the various processes that a word may show during its formation. These processes may involve affixation, letter shifting or sometimes deletion, among other processes. Of course, these changes take the form of patterns which have to comply with the language morphological scale. Examples to show how the morphological scale works are:

$$
\begin{aligned}
& \text { 1-ta } \int \text { a adsur } \\
& \int d j \mathrm{j} \\
& \text { fC } 1 \\
& \text { tafaa? } 1 \\
& \text { 2-istibaanat } \\
& \text { byn } \\
& \text { fC } 1 \\
& \text { istif } C \text { alat }
\end{aligned}
$$

In the first example, (t a $\int a$ a $\left.d\right\}$ ur) there isn't either deletion or shifting in the root $\left(\int \mathrm{d} r\right)$. However, in (istibaanah) both deletion and replacive shifting occur; in the verb (bayan), the [ya] is deleted. As a result, the [C] of the morphological scale is deleted also and the morph ( $\mathrm{t}$ ) is added at the end of the noun. It should be emphasized that in Arabic it is not acceptable to produce several stems from roots without considering the limitations of MSA root productivity, (Ibrahim, 2010).

Affixation also works as part of the pattern formation. For example, the prefix $-m u$ is a morpheme used with participles which are derived from the verb, active or passive. Consequently, it can be part of the patterns such as mufGil (e.g., mumkin 'possible,' or mushrif 'supervising') or mufta Çal (e.g., muћtaram 'respected'). This shows how the Arabic language is systematic in the word-building process (Bohas, Guillaume, \& Kouloughli, 2006).

\section{The Active Participle in MSA}

The active participle is a form which is used in MSA as well as its varieties. It indicates the agent or doer of an activity such as teacher, writer, copier, worker, and director in the English language.

In MSA, the active participle has many patterns which can be listed as follows:

1- With trilateral roots in which the /C/ (second consonant) of the verb is followed by the vowel /aa/, the active participle follows the pattern faaCil . The following are examples where the trilateral verb and active participle are listed consecutively, (Ziadeh \& Winder, 2003). 


$\begin{array}{lll}\text { kataba } & \text { kaatib } & \text { 'writer' } \\ \text { nasaxa } & \text { naasix } & \text { 'copier' } \\ \text { Camila } & \text { Caamil } & \text { 'worker' } \\ \text { qaqḍa } & \text { qaadi } & \text { 'judge' }\end{array}$

However, if the verb has / $\mathrm{u} /$ vowel or đamma, it follows the pattern faCiil such as:
dią̧ufa
dạ̧iif
'weak'

Halwani (1993) mentions that with hollow verbs, which have the long vowel /aa/ in the middle, the active participle follows the pattern faa?il. This is the case where the /C/ of the verb is transformed into a hamza / $/$. Examples of this pattern are:

\begin{tabular}{|c|c|}
\hline baaৎa & baa?ic \\
\hline naama & na?im \\
\hline
\end{tabular}

2- With quadrilateral roots, the active participle follows the following pattern:

- Using the imperfective form of the verb, then substituting its marking consonant (y) with mu- and using a kasra for the pre-final consonant, thus producing the pattern mufCil. Examples are:

$\begin{array}{llll}\text { aslama } & \text { yuslimu } & \text { muslim } & \text { 'Muslim' } \\ \text { aћsana } & \text { yuhsinu } & \text { muћsin } & \text { 'benefactor' } \\ \text { anÇama } & \text { yunÇimu } & \text { munÇim } & \text { 'granter' }\end{array}$

Schulz (2004).

\section{The Active Participle in the Rural Palestinian Dialect (RPD)}

The Palestinian society has known a great deal of turmoil and destruction for a long time as it has been divided, and colonized and forced to learn other languages. This complicated the linguistic scene in Palestine. However, the Palestinians have been able to maintain their linguistic identity as Arab Muslims. Hallloon (2009) asserts that despite the various forms of colonization under which the Palestinian community fell, morphological patterns have been the least categories varying from MSA.

RPD is the variety spoken in Palestinian countryside and by Palestinians outside, who come from rural backgrounds but have maintained it for more than 60 years of exile. After meeting with members of native Palestinian, including the researcher's family members, the following patterns were found. The researcher compared the patterns with MSA.

1- Using the pattern faÇaal instead of faaÇil with trilateral verbs.

Examples:

$\begin{array}{llll}\text { kaðaba } & \text { kaððaab } & \text { kaðib (MSA) } & \text { 'lier' } \\ \text { xadama } & \text { xaddaamih } & \text { xaddima (t) (MSA) } & \text { 'female servant' }\end{array}$

It should be emphasized that faÇaal is a noun of intensity in MSA, which shows a great deal of the noun, and follow the pattern faÇaal. Rural Palestinians tend to use these patterns so frequently as in the examples stated above. Other examples are 'sayyah nayyah' to show the vastness of the house, and 'kassiib' for the person who earns a big amount of money.

2- Producing the pattern fuuclaan/ faÇlaan instead of faaÇil in MSA. An example of this is:

$\begin{array}{llll}\text { dzaąa } & \text { dzuuçaan } & \text { dzaa?iC(MSA) } & \text { 'hungry' } \\ \text { zahiqa } & \text { zahkaan } & \text { zahiq(MSA) } & \text { 'bored' }\end{array}$

3- In other trilateral patterns, Palestinians tend to also add the suffix $-i$ at the end of active participles which are formed from defective verbs such as qaḍa, and mafa.

$\begin{array}{lll}\text { PRD } & \text { MSA } & \\ \text { kaḍi-I } & \text { Qạ̣i } & \text { 'judge' } \\ \text { mafi-i } & \text { mafi } & \text { 'walker' } \\ \text { daÇi-i } & \text { daÇi } & \text { 'propagandist' }\end{array}$

In these examples, the $-i$ in MSA marks the kasra, whereas, the $-i i$ in PRD marks the consonant $/ \overline{1} /$ in Arabic. 
This distinction is caused by nunation in MSA. Examples to illustrate this are:

MSA

haaða qaadi

zarana daaÇi

\section{PRD}

haaða qadi-i

zarana daaÇi-i
'This is a judge'
'we were called on by a
propagandist'

Qaadi and daa $\zeta_{i}$ here are marked with $-i$ (kasra) due to nunation. In non-nunated constructios, MSA retains the ii (consonant $\overline{1}$ ), which shows conformity between it and PRD. Example of non-nunated constructions in MSA are: marra alqa di-I 'the judge passed' and ansaftu alfaaki 'I was fair with the defendant.'

4- There are patterns used in PRD which are derived from trilateral geminated roots in MSA such as (habba, hassa, halla, falla), For example:

ћab-ib

'lover of'

ћal-il

'solver'

fal-il

'a runner away'

In fact, this pattern in PRD indicates a derived active participle (as they represent the person who does the action). However, the researcher looked for a similar derivation in MSA and found hall 'solver' and radd 'replier,' (Ryding, 2014). These forms indicate a geminated $/ / /$ and $/ d /$ not doubled ones as in PRD (hal-il, rad-id).

5- Sometimes PRD speakers use the active participle instead of the passive participle (e.g., mașoon 'preserved', mutawwafaa 'deceased') in constructions such as as hakkak musaan 'your right is preserved, and abooh mitwwafi 'his father has passed away.' According to Ryding (2014), the MSA version of these constructions is the passive participle: ћakkak masuun, and aboohu mutawwafaa.

6- PRD speakers use the pattern mif̧̧il instead of the pattern mufGil in MSA. Examples are:

\section{MSA}

mu-slim

mu-ћsin

mu-nÇim
PRD

$\begin{array}{ll}\text { mi-slim } & \text { 'Muslim' } \\ \text { mi-hsin } & \text { 'benefactor' } \\ \text { mi-nCim } & \text { 'granter' }\end{array}$

As mentioned above, MSA forms active participle from quadrilateral verbs by replacing the imperfective marking consonant (y) with $m u$ - and using a kasra for the pre-final consonant, thus producing the pattern mufÇil. These examples show that PRD speakers partially retain the way the active participle is formed in MSA as they keep the -i-(kasra), but use the prefix mi- instead of $m u$ - of MSA.

It is noteworthy to mention that there are several derivational affixes used in the Palestinian dialect, which do not exist in MSA. These forms are the result of foreign influence on Palestine throughout history and contact with neighboring countries. Some of these affixes are:

1- Some noun which refers to the agent are derived by adding the suffix -ji. This suffix is usually used to indicate people's professions. Examples are:

$\begin{array}{ll}\text { Kundar-ji } & \text { 'shoe mender' } \\ \text { kahwa-ji } & \text { 'coffee maker' } \\ \text { Kabab-ji } & \text { 'kebab seller' } \\ \text { Hamam-ji } & \text { 'pigeon seller' } \\ \text { kola-ji } & \text { 'goal keeper' }\end{array}$

2- Adding the prefix baf- to career nouns such as muhandis (engineer), kateb (clerk).

Examples:

Baf-muhandis

Baf-katib

In the examples, kateb and muhandis are derived according to MSA patterns. However, the prefix baf- does not exist in MSA. It is one of the prefixes which the Palestinians adopted from Turkish in addition to the suffix -ji during the Turkish rule over Palestine. In the Palestinian rural society, the prefix baf- is used as a title which shows respect and a good social and professional rank (Hallloon, 2009). 


\section{Conclusion}

This study aimed to analyze the active participle used in MSA and RPD. The data for this study were collected from different sources. The analysis of the data revealed the patterns used in MSA. These patterns were listed and investigated morphologically. The PRD was also examined in order to find the different patterns. It was

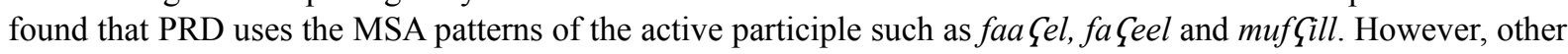
different patterns were found and were morphologically examined. These forms showed that PRD active participle did not only vary morphologically from MSA, but it also developed some affixes which are non-Arabic at all such as -ji and baf-. The researcher would like to point out that the limited framework of this study did not make it possible to make an extensive examination of the active participle. The researcher believes that PRD morphology deserves a more comprehensive study.

\section{Acknowledgements}

The researcher is very grateful to the Research Centre at the Faculty of Arts at King Saud University for funding this research.

\section{References}

Abdel-Monem, A., Shaalan, K., Rafea, A., \& Baraka, H. (2009). Generating Arabic text in multilingual speech-to-speech machine translation framework. Machine Translation, 22(4), 205-258. https://doi.org/10.1007/s10590-009-9054-9

Aronoff, M. (1994). Morphology by Itself: Stems and Inflectional Classes. MIT Press.

Bauer, R. S. (2000). Hong Kong Cantonese and the Road Ahead. In C. S. David, A. L. Li, \& W. K. Tsang (Eds.), Language and Education in Postcolonial, Hong Kong (pp. 35-58). Hong Kong: Linguistic Society of Hong Kong.

Bohas, G., Guillaume, J. P., \& Kouloughli, D. (2006). The Arabic Linguistic Tradition. Washington, D.C.: Georgetown University Press.

Ferguson, C. F. (1959). Diglossia. Word, 15(2), 325-340. https://doi.org/10.1080/00437956.1959.11659702

Halloon, M. (2009). Al-Lahjah Al-Sha'biyyah [The Popular Dialect]. A research paper presented in the Oral Heritage Conference in Bethlehem University.

Halwani, M. K. (1993). Al-Mughni Al-Jadiid fi Elm Al-Sarf [The New Sufficient Book on the Science of Morphology]. Beirut: Dar Al-Sharq Al-Arabi. 446 pp.

Hudson, G. (1985). Arabic Root and Pattern Morphology without Tears. Journal Linguistics, 22, 85-122 https://doi.org/10.1017/S0022226700010574

Ibrahim, A. I. (2010). Noun Formation in Standard English and Modern Standard Arabic: A Contrastive Study. Journal of Language Teaching and Research, 1(5), 614-623. https://doi.org/10.4304/jltr.1.5.614-623

Neme, A., \& Laporte, É. (2013). Pattern-and-root inflectional morphology: The Arabic broken plural. Language Sciences. https://doi.org/10.1016/j.langsci.2013.06.002

Ryding, C. K. (2005). A Reference Grammar of Modern Standard Arabic. Cambridge University Press, 708 pages.

Ryding, C. K. (2014). Arabic: A Linguistic Introduction. Cambridge University Press.

Schulz, E. (2004). A Student Grammar of Modern Standard Arabic. Cambridge University Press.

Ziadeh, F. J., \& Winder, R. B. (2003). An Introduction to Modern Arabic. Dover Publications INC. Miniola, New York.

\section{Copyrights}

Copyright for this article is retained by the author(s), with first publication rights granted to the journal.

This is an open-access article distributed under the terms and conditions of the Creative Commons Attribution license (http://creativecommons.org/licenses/by/4.0/). 